\title{
14. Innocence and Trauma in J.D Salinger's The Catcher in the Rye
}

Fikret GÜVEN 1

Rita ÖZCAN²

APA: Güven, F.; Özcan, R. (2021). Innocence and Trauma in J.D Salinger' s The Catcher in the Rye. RumeliDE Dil ve Edebiyat Araştırmaları Dergisi, (Ö9), 170-176. DOI: 10.29000/rumelide.981517.

\begin{abstract}
The Catcher in the Rye is a bestselling novel, based on experiences of protagonist' s expulsion from a boarding school and his travel back to his home. He spends his days trying to get someone listen to him in a meaningful way and share his fears about becoming an adult and its accompanying corruption of innocence. However, he is obsessed with and protective of innocence. He tries to reach out to people on several occasions who could comfort him for his fears of growing up: friends, teachers, cab drivers, prostitutes, and nuns. However, he can never ask those questions directly or find a meaningful companion to share his fears. In reality, what Holden seeks after is not sex, money or any other motive; he wants to freze the time and keep the things the way they are. He wants to be the protector of innocence, and stay innocent himself. His subtle obsesssion is tested on several occasions that his interest in sexuality becomes so abusive at every attempt. His interactions with adult world strikes him as "phony" because every adult he comes into contact with has ulterior reasons. This is why, he wants to freeze the time for himself and people that he cares about. All these intense experiences led him to break down and ends Holden up in a mental institute. The paper presents a psychoanalytic approach to the themes of innocence of childhood and phony adulthood in the selected text.
\end{abstract}

Keywords: Holden, Innocence, trauma, sexual abuse, J.D. Salinger

\section{J.D. Salinger'in Çavdar Tarlasındaki Çocuklar' da Masumiyet ve Travma}

$\ddot{0} \mathbf{z}$

Çavdar Tarlasında Çocuklar, ana kahramanın yatılı bir okuldan uzaklaştırılması ve evine dönüş yolculuğuna dayanan tüm zamanların çok satan bir romanıdır. Ana karakter günlerini birinin onu anlamlı bir şekilde dinlemesini sağlamaya ve yetişkin olma korkularına ve buna eşlik eden masumiyet yozlaşmasına yanıtlar bulmaya çalışarak geçirir. Ana karakter masumiyetin korunmasına takıntılı bir görüntü sergiler. Arkadaşları, öğretmenleri, taksi şoförleri, fahişeler ve rahibeler gibi yetişkinlere büyüme korkusu konusunda kendisini teselli edebilecek insanlara birkaç kez ulaşmaya çalışır. Bu soruları asla doğrudan soramaz veya korkularını paylaşacak anlamlı bir arkadaş bulamaz. Gerçekte, Holden'ın aradığı şey seks, para ya da başka bir amaç değildir; sadece zamanı dondurmak ve her şeyi olduğu gibi tutmak istemektedir. Masumiyetin koruyucusu olmak ve aynı zamanda kendisi de masum kalmak istemektedir. Onun bu saplantısı, cinselliğe olan ilgisi her girişimde kötü bir sonla test edilir. Yetişkin dünyasıyla olan etkileşimleri ona "sahte" gelmektedir çünkü temas ettiği her yetişkin, ona çıkarcı bir şekilde yaklaşır. Bu yüzden kendisi ve değer verdiği insanlar için zamanı dondurmak ister.

Dr. Öğr. Üyesi, Nişantaşı Üniversitesi, İktisadi ve İdari Bilimler Fakültesi, İngiliz Dili ve Edebiyatı (İstanbul, Türkiye) fikret.guven@nisantasi.edu.tr, ORCID ID: 0000-0002-9313-7166 [Araştırma makalesi, Makale kayıt tarihi: 02.07.2021kabul tarihi: 20.06.2021; DOI: 10.29000/rumelide.981517]

Öğrenci, Nişantaşı Üniversitesi, İktisadi ve İdari Bilimler Fakültesi, İngilizce Mütercim ve Tercümanlık, (İstanbul, Türkiye), ritakalocsa@hotmail.com, ORCID ID: 0000-0003-1544-3974

Adres | Address

RumeliDE Dil ve Edebiyat Araştırmaları Dergisi Osmanağa Mahallesi, Mürver Çiçeği Sokak, No:14/8 Kadıköy - ISTANBUL / TÜRKIYE 34714 e-posta: editor@rumelide.com

RumeliDE Journal of Language and Literature Studies

Osmanağa Mahallesi, Mürver Çiçeği Sokak, No:14/8

Kadıköy - ISTANBUL / TURKEY 34714 tel: +90 $5057958124,+902167730616$

e-mail: editor@rumelide.com,

phone: +90 5057958124 , +90 2167730616 
Tüm bu yoğun deneyimler Holden' in yıkılmasına ve kendini bir akıl hastanesinde bulmasına sebep olur. $\mathrm{Bu}$ çalışma, seçilen metindeki çocukluk masumiyeti, sahte yetişkinlik temalarına bir yaklaşım sunmaktadır.

Anahtar kelimeler: Holden, Masumiyet, travma, cinsel taciz, J.D. Salinger

\section{Introduction}

Jerome David Salinger expresses strong criticism in his novel over the society that failed to protect innocence. Serving in World War II actively and seeing some of its most fierce battles, Salinger was institutionalized for depression and suffered post-traumatic stress disorder after the war. Upon his discharge from the hospital, instead of writing about the horrors of the war, he wrote a novel that presents the importance of innocence and its preservation. The novel deals with the crucial issues such as depression, alieneation, and the challenges of communication. Themes of phoniness, childhood innocence, sex, and identity make The Catcher in the Rye a powerful and provacative novel. While recounting the events that locked him up in a mental institute, the main character, Holden, wants to stop the time and hold on to purity and innocence. He cannot bear the thought of belonging to the adult world which is highly superficial, materialistic and corrupted. His only dream is to save innocent children from becoming part of this cruel world. He describes his ideal occupation herocially as: "I have to catch everybody if they start to go over the cliff-I mean if they're running and they don't look where they're going I have to come out from somewhere and catch them. That's all I'd do all day. I'd just be the catcher in the rye and all" (p.173).

What makes this story so remarkable is his fixation on an idealized past and unsuccessful attempts at replacing this idealized past with a more useful one. Holden is a unable to abandon his childhood, which in turn makes it impossible for him to complete his transition to adulthood. The paper analyzes the selected text psychoanalytically and discusses themes of innocence of childhood and phony adulthood.

\section{Childhood innocence and phony adulthood}

Holden has lost his brother Allie and this loss has left a big void in his psyche. His mind is constantly occupied with a mourning and with what it actually represents for him. However, his affection can be seen more than brotherly love: Holden wishes to be the mere object of his mother's desire. Allie was indeed the object of Holden's mother's desire and attention. To replace his absence, Holden tries to become the object of her mother's devotion. Allie further symbolizes a period in his life when he felt perpetual happiness which can no longer be revived. This is similar to Lacanian approach, where the child feels "the initial state of blissful union" (Homer, 2005, p. 55). The loss of childhood innocence is part of an inevitable natural process that is independent of whether the "insiders" want it or not (Steinle, 2009). In later phases, the child slowly recognizes that he is not the only object of mother's devotion, and that her desire is directed elsewhere, namely father. This is the first time when the boy realizes that it lacks something that it can provide the mother with. Hence, the child will try to recapture the mother's attention. After Allie's death, Holden's parents' attitude towards their remaining children is of indifference. Holden's tries to re-establish the broken bond. When Holden says: "my mother, she still isn't over my brother Allie yet" (Salinger, p. 201), it is evident that Holden wants what his dead brother possessed and what he himself lacks. Allie's catcher mitt is highly symbolic in this aspect. The night of his brother's death, Holden breaks his hand. He receives the attention and desire that he was seeking by injuring himself. Another significant artifact that forms a link is Holden's red hunting hat. A memory from his childhood that reminds his brother's hair color. The mitt and the hat together serve to complete a recurrent symbol; that of Holden as a catcher. As much as Holden seeks

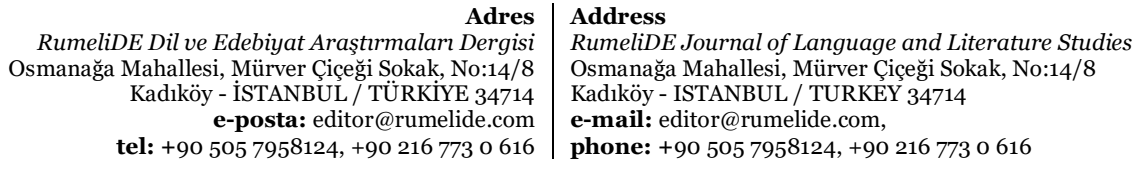


the love of his parents, deep down inside he is aware of the impossibility of this. So in order to handle, he has adopted certain cope mechanisms, namely invoking fantasies. Fantasy can be described as "an imagined scene in which the subject always represents the fulfillment of a wish in a manner that is distorted to a greater or lesser extent by defensive processes" (Homer, p. 85).

Holden's fantasies serve as a safe haven from the fears of death, loss and pain of coming of age. There are two memorable fantasies he takes refugee in when threatened. The first occurs following his confrontation with the elevator attendant Maurice. The other fantasy involves where he imagines his own funeral following his unsuccessful attempts at communication with his girlfriend Sally. Holden has just boarded in a cheap motel. The elevator attendant offers Holden an opportunity to have sex. When the prostitute shows up at his door the grim reality of losing his virginity causes him to reconsider his earlier misconceptions. He is unable to get himself to perform the act. He tells Sunny that he cannot have sex because he recently had an surgery on his "clavichord". He comes up with such an absurd excuse, because sex is an act belonging to the adult realm. Having sex would be an initiation for Holden to enter this realm. What he wants on the contrary is to stay in the safe zone of the childhood innocence. Therefore, Holden avoids the defiling nature of sex. It is an experience with no return, once it is realized there is no turning back to innocent state. Jonathan Baumbach claims that for all his avowed 'sexiness', he is an innocent, and his innocence-impelled fear dampens his desire (Baumbach, p. 69).

After Maurice tries to exhort money from him, Maurice snaps a finger on his pajamas which hurts physically as well as mentally. Holden explains; “he snapped his finger very hard on my pajamas. I won't tell you where he snapped it, but it hurt like hell (p. 135). After this humiliation, Holden finds himself fantasizing. Once he is back to reality, his real emotions come to surface: "I felt like jumping out the window" (p. 137). Holden's failed attempt of initiation into the adulthood causes a fantasy about his own funeral. At a later occasion, Holden takes a walk in the Central Park looking for the ducks. During his visit, he breaks a music record that he bought for his sister Phoebe. This causes a great deal of pain for Holden, because the record is a symbol for the innocence of childhood. Holden is reminded once more of the impossible task of staying in the safe zone of childhood. He is once again overwhelmed with fear and imagines his own death "I started picturing millions of jerks coming to my funeral and all" (p. 202). His guilt over not being present in Allie's funeral and his desire to replace him in his mother's devotion cause a death fantasy which will maintain both of his wishes.

His most consistent fantasy is being being 'a catcher in the rye'. He hears those phrases on the street from a younger kid. By replacing the word "meet" with "catch", Holden turns the whole meaning of the poem upside down. In reality, the poem deals with the themes of sexual intimacy, whilst Holden's interpretation of it is strictly about preserving childhood innocence. The indication here reaffirms Holden's attempts at solving his personal conflicts by means of succumbing to fantasies. The significance of his "catcher fantasy", however, reaches a climactic point when Holden visits his sister. Holden finds Phoebe sleeping on his older brother' s bed. Not surprisingly, when Holden shows up, his parents are away. As always, they are not present when he needs them the most. He is forced to fill the void left by their absence with alternative figures. Phoebe proves to be the best candidate for this particular task. Upon finding out that his brother has been expelled from Pencey, Phoebe' s first reaction is to say "Daddy'll kill you" (p. 215). This statement is significant; what Holden will receive from his parents is not empathy but punishment. In his words, the worst punishment he will receive from his father is to be sent to a military school. At a time when American middle-class families preferred to send their children to boarding schools and give away the responsibility of raising their children, Holden will be no exception. These schools had permission from the families to educate and shape the children. Inevitably, the emotional bond between child and parent loosens up. Holden

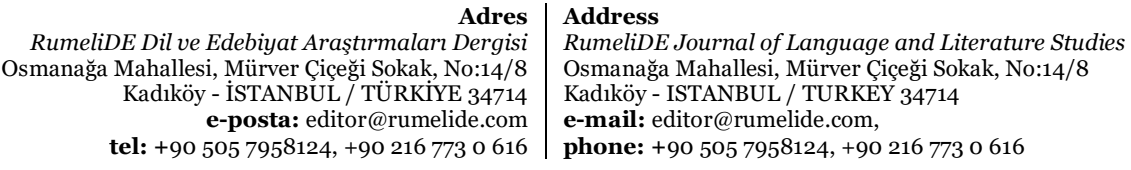


without the support of his family, forced to cope with the difficulties of the world, watches the people around him and the environment and then moves more and more away from this medium (Sasani \& Javidnejat, 2015). Thus, Holden lacks and seeks parental love, empathy, and support, instead he is responded with scorn and further alienation. His parents sent him away to boarding schools where he will be deprived of their love, and further negligience breaks his hearth to the core. What Holden actually needs is a capable father figure in his life that will guide him through the transition from the childhood to the adulthood and comfort his fears of growing up.

Holden comes across several figures who are expected to realize this role, but they all fail. The prime example among these characters is Holden's father. Absent from his son's life, Holden's view on his father's job tells a lot about the relationship between them. When his sister asks Holden if he would like to be a lawyer when he grows up, he answers; "it doesn't appeal to me," (p.224). Holden thinks of his father as a fraud. Lawyers are supposed to protect innocence. However, just as lawyers are unable to rescue the innocent, Holden's father will not be able to protect his own son's innocence. As a mentor or advisor, he is destined to fail. Other than his biological father, many other characters in the novel appear as role models to Holden who may be of help to him in resolving his transitional fears. Some of them are his teacher Mr. Spencer who tells Holden that life is a game which needs to be played according to the rules (p.12), his older brother D.B. whom Holden calls as a "prostitute" because rather than writing genuine literature, he preferred to write scripts for movies, Carl Luce, an old student advisor who constantly pretends to be an expert on sexual issues, and Mr. Antolini, Holden's former English teacher. All these characters fail at helping Holden out on the fears of the transition from childhood to adulthood.

Holden' former teacher Mr. Antolini is a significant figure. What makes him an important persona in Holden's life is an event that occurred in Elkton Hills Prep School. One of Holden's classmates, James Castle, jumps from the window and commits suicide. Mr. Antolini picks up his body from the floor after the ordeal. The night he committed suicide, he was wearing the turtleneck sweater he had borrowed from Holden. What makes Mr. Antolini's gesture of picking up James Castle after his death so significant is clarified by Jonathan Baumbach; "he was unable to catch James Castle or prevent his fall; he could only pick him up after he had died. (Baumbach, p. 65) Holden looks up to Mr. Antolini as a father figure, however his failure at saving or catching James Castle before the fall makes him another disappointment. Patting Holden on the head in a homosexual manner, he crosses a line and defiles the sanctity of companionship. This act places him among other failed father figures in Holden's conciousness. Holden's disenchantment with his old teacher's lack of success at guiding him intensifies Holden's fears and anxiety.

\section{Fear of death and passage to adulthood}

Holden's obsession with certain objects such as the Egyptian mummies, frozen lagoon in the Central Park, his feelings toward old and deceased people, his contemplations about suicide are all indication of Holden's fear of death. Holden, as a teenager has formed a strong connection with his dead brother's image. This identification with Allie serves as a bond that constitutes Holden's precarious ego. In his world of chaos, Allie's memory proves to be stabilizing anchor and unifying safeguard against the turbulent ordeals. Allie "functions to provide coordination in the midst of internal anarchy, to establish organization in the field of a primal discord" (Boothby, 1991: 24). By channeling his anger and frustration towards external causes he tries to maintain the composure of self. His violent tendencies therefore are really reflections of repressed emotions. Picking up fights with Maurice and Stradlater and projecting this humiliation into death fantasies are solid indicators of Holden's fear of death. Holden further notes that people are unreliable and do not give messages to one another (Shaw \& Salzman, 1991). Holden succeeds in soothing these destructive urges

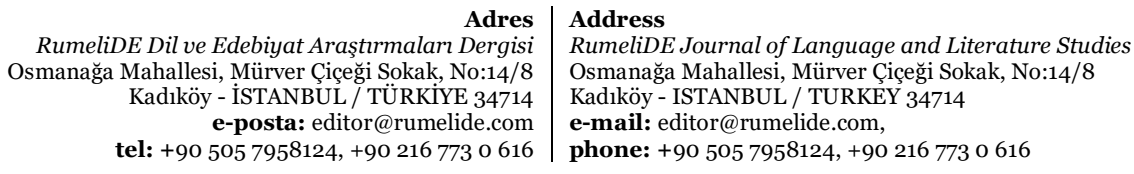


temporarily by channeling their course, however on the long run his death related fears are overwhelming. His insistence of "holding onto" idealized images of people like Allie and his efforts to maintaining innocence only reinforce his morose fantasies. The harsh reality of death is an image that he cannot fathom. Neverthless, his greatest challenge in the novel will be to triumph over this terrifying feeling. What enables him to master his anxiety is his acknowledgement of the interconnected state of life and death.

Life begins with sex and Holden is extremely curious about it. Though he does not hide his enthusiasm in sexual activity, he is aware that it will bring about the death of the innocence he is struggling to maintain. The decisive moment which marks the shift in his understanding towards the dynamics of sex occurs when Holden discovers that someone has written 'Fuck You' signs all over Phoebe's school's walls. He tries to protect children from learning about sex in this misguided context, and attempts to erase the signs (Rosen, p. 105). However, as much as he tries there will always be more of those signs that it is impossible to get rid of them permanently. Holden reiterates this idea when he comments that: "If you had a million years to do it in, you couldn't rub out even half the "Fuck You" signs in the world (Salinger, p. 262). When he descends into the mummy's tomb during his visit to the museum, he is greeted by another 'Fuck You' sign. He slowly comes to terms with the unavoidable nature of sex and death. Sex and death, agents of adulthood, which continually try to disintegrate Holden's precarious ego composed of his identification with Allie and the everlasting static safety provided by the museum, eventually help Holden realize that change should be embraced, not something to be feared.

Phoebe stands as the ultimate model to help Holden's anxiety about this transition. She serves as a bridge for Holden's desire to replace Allie in the familial structure and a safe habitat. Also because of her age, she is a symbol of childhood innocence, and the reminder of the inevitable reality of adulthood. If Holden wants to resolve any issues regarding his rite of passage, it will only become possible through Phoebe. Phoebe's nature as the preserver of purity and the initiator of maturity blends well with the psychological transition that Holden is in. Since he exhausted all possible options of assistance from the adults, Holden now has to find someone who can truly emphathize with him without any prejudice. Phoebe fills the void left by his absence in Holden's unconscious by being the reminiscent image of Allie. Also by being the person with whom Holden shares the secret of his innermost desire in the climactic scene of the novel, Phoebe comes to embody paternal functions in helping Holden express his real emotions. The scene itself points to how neglectful and indifferent their parents have been towards their children. He comes home after a horrid night spent in the streets of New York to seek support and empathy. Conveniently, his parents are away at a party. From this point on Phoebe will be the only provider of paternal support for Holden.

The conversation between them revolves around Holden's disappointment with the adult world and his inability of letting go. Unlike the adults who constantly give advice to him and impose their views upon him, Phoebe proves to be an excellent listener and instead of criticizing his brother, she tries to comprehend what he has been going through. When Holden mentions that the only thing he likes in this world was his deceased brother Allie, by indifference, Phoebe forces Holden to realize the impossibility of returning him back to life. Gerald Rosen asserts, this is an upside- down situation in which the younger person protects the older one and gives him advice in line with the whole pattern (Rosen, p. 107). The sudden shift of roles crushes Holden's sole to the core. The emphasis over his parents' inability to support Holden is made more explicit when Holden's mother arrives home while her children are talking. Holden was smoking in the room before her arrival so he hides in the closet to avoid a confrontation. Mrs. Caulfield kisses her daughter goodnight and leaves the room without questioning Phoebe. Devoid of good examples, Phoebe becomes a geniune redemptory figure: "Whereas all of the adults in his world fail him, and he, in consequence, fails them, a ten year old girl, whom he protects as catcher in the rye, saves him - becomes his catcher"

Adres

RumeliDE Dil ve Edebiyat Araştırmaları Dergisi Osmanağa Mahallesi, Mürver Çiçeği Sokak, No:14/8 Kadıköy - ISTANBUL / TÜRKIYE 34714 e-posta: editor@rumelide.com tel: $+905057958124,+902167730616$
Address

RumeliDE Journal of Language and Literature Studies

Osmanağa Mahallesi, Mürver Çiçeği Sokak, No:14/8

Kadıköy - ISTANBUL / TURKEY 34714

e-mail: editor@rumelide.com,

phone: +90 $5057958124,+902167730616$ 
(Baumbach, p. 71). She comes to represents both the catcher and the caught in Holden's pschye. She gradually develops into a figure providing Holden with what he had been looking for all along; an innocent child in desperate need of protection from the phony adult world, resembling Holden's own desire, and also a wise mentor pointing Holden in the right direction, saving him from the fall.

After his confrontation with Mr. Antolini, it is once again Phoebe and her gradual influence on him that forces Holden to reconsider his earlier misconceptions. Holden, before leaving for good, decides to see Phoebe for one last time and asks her to meet him in front of the museum. Phoebe shows up dragging a suitcase. This particular condition of Phoebe is literally an awekening point for Holden, because as soon as he realizes how his action may be interpreted by Phoebe, he backs up from it. "he has become an older sibling mentor to his own little sister" (Miltner, 2009, p. 164). The last scene of them together in the park, with Phoebe riding the carousel and Holden watching her from a distance, indicates both Holden's redemption and his realization of the adulthood. Holden has gained a new perspective and role that reveals his new understanding of the imperative of letting it go, of letting his guard down and allowing Phoebe to grow up when he utters: "If they fall off, they fall off, but it's bad if you say anything to them. (Salinger: 273274) Holden has abandoned his being a catcher fantasy along with his fears. He becomes aware that the fall from innocence is inevitable. By embracing this new attitude, Holden also breaks away from Allie's spell. He identifies his fate with Allie's as he sits under the pouring rain in front of the carousel. He lets go of his hold on the vision of the dead brother. The image of the catcher in the rye, which is an impossible fantasy to live up to and keeps Holden imprisoned in the childhood, is replaced by a more promising image of the constantly going around carousel, the acceptance of the cycle of life and personal integrity, the inevitable loss of childhood and the importance of communal bonding as displayed by. Holden preferring to stay with the adults instead of riding the carousel. Watching Phoebe carousel ride brings Holden an enjoyment similar to that of the parents of the other children. He slowly joins the ranks of adults by being a chaperone to his little sister. He invites the reader to share his exhilaration and joy when he says: "God, I wish you could've been there" (Salinger, p. 275). He successfully completes his passage from childhood to adulthood.

\section{Conclusion}

The paper analyzed the text psychoanalytically and discussed themes of innocence of childhood and phony adulthood. Being anti-social persona at the beginning of his journey, Holden placed himself in a position outside of society's reach. His personal rebellion grew out of a sense of irrecoverable loss of innocence in conjunction with his belief that the adult world would not be able to provide him with the necessary support to cope with his vicarious anxieties. While narrating his story to the reader, however, his second viewing of events soothes his anger, and replaces it with those of tolerance and compassion. With his sister's lead, he admits the burden of growing up. The closing lines of the story reaffirm Holden's rite of passage into adulthood. He confesses that he sort of misses everybody, pointing to his yearning and desire to form healthy relationships with the external world. The narrator Holden is clearly now a totally different person than the Holden who experienced all the ordeals. Throughout the story he looked for someone to listen to him. In the end, however, he managed to have millions of readers to listen to what he had to say. His identification with his dead brother Allie and his fantasies about being a catcher delayed his transition from childhood to adulthood. His anger against the "phony" adult life was based on his feelings about loss and death. However, he resolves this dilemma with the help of Phoebe. She demonstrates Holden that growing up is a natural process and that he cannot bring back his past. Following his sister's lead, Holden embraces the transformation. The bond between the protagonist and the community is established and Holden has successfully completed his progress from the childhood into the adulthood. He will likely find a secure place for himself among the adult world after he leaves the mental institute and rejoin society successfully.

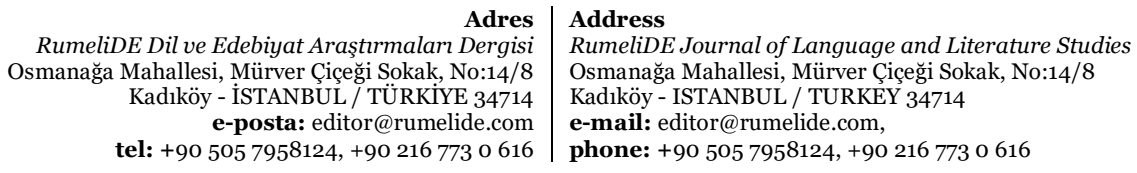




\section{References}

Aubry, T. (2015). The Catcher in the Rye: The Voice of Alienation, The Gilder Lehrman Institute of American History, New York.

Baumbach, J.(1990). “The Saint As A Young Man”, Holden Caulfield, Ed. by Harold Bloom, New York, Chelsea House Publishers, p. 65-73.

Bloom, H. (2014). JD Salinger's the Catcher in the Rye, Infobase Publishing, New York.

Homer, S. (2005). Routledge Critical Thinkers: Jacques Lacan, New York, Routledge, 2005.

Lacan, J. (2006). Écrits: The First Complete Edition in English,Ed. by Bruce Fink, Héloïse Fink and Russell Grigg,Trans. by Bruce Fink, New York, W.W. Norton and Company, Inc.

Salinger, J. D.(1951). The Catcher In The Rye, New York, The Modern Library.

Boothby, R. (1991). Death And Desire: Psychoanalytic Theory in Lacan's Return To Freud, New York, Routledge, 1991.

Sasani, S., \& Javidnejat, P. (2015). A Discourse of the Alienated Youth in the American Culture: Holden Caulfield in JD Salinger's The Catcher in the Rye. Asian Social Science, 11(15), p. 204-210.

Shaw, P., \& Salzman, J. (1991). Love and Death in the Catcher in the Rye, Cambridge University Press, New York.

Steinle, P. H. (2009). The Catcher in the Rye as Postwar American Fable. Bloom's Modern Critical Views, Infobase Publishing, New York.

Robinson, K. H. (2012). Innocence, knowledge and the construction of childhood: The contradictory nature of sexuality and censorship in children's contemporary lives, Routledge Publishing, London.

Rosen, G. (1987). “A Retrospective Look at The Catcher in the Rye”,Modern Critical Views: J.D. Salinger,Ed. by Harold Bloom, New York, Chelsea House Publishers, p. 95-109.

Miltner, R. (2009). "Mentor Mori; or, Sibling Society and The Catcher in the Bly",Bloom's Modern Critical Interpretations: J.D. Salinger's The Catcher In The Rye, New Edition,Ed. by Harold Bloom, New York, Infobase Publishing, p. 151-166.

RumeliDE Dil ve Edebiyat Araştırmaları Dergisi Osmanağa Mahallesi, Mürver Çiçeği Sokak, No:14/8 Kadıköy - İSTANBUL / TÜRKIYE 34714 e-posta: editor@rumelide.com tel: +90 $5057958124,+902167730616$
Address

RumeliDE Journal of Language and Literature Studies Osmanağa Mahallesi, Mürver Çiçeği Sokak, No:14/8

Kadıköy - ISTANBUL / TURKEY 34714

e-mail: editor@rumelide.com,

phone: +90 5057958124, +90 2167730616 